\title{
Movement of adult German cockroaches, Blattella germanica (Linnaeus), from an occupied harbourage shelter to a vacant new shelter 3. Interaction between males and females
}

\author{
Tomoya Takahashi ${ }^{1,2)}$, Hideakira Tsuji ${ }^{3)}$, Nobuko Watanabe ${ }^{1)}$ \\ and Masayoshi HaTSUKADE ${ }^{2)}$ \\ 1) Fuji Environmental Service Co., Ltd., 5-5-7 Hirono, Shizuoka, 421-0121 Japan \\ ${ }^{2}$ Laboratory of Applied Entomology, Faculty of Agriculture, Shizuoka University, 836 Oya, \\ Shizuoka, 422-8017 Japan \\ ${ }^{3)}$ KSK Institute for Environmental Biology, F-409, 2-1 Nishino-Rikyu-cho, \\ Yamashina-ku. Kyoto, 607-8345 Japan
}

(Received: 22 December 1997; Accepted: 15 June 1998)

\begin{abstract}
Key words: German cockroach, Blattella germanica, individual movement, shelter, interaction
\end{abstract}

\begin{abstract}
When a harbourage shelter occupied by marked cockroaches was placed in one of two compartments divided by a partition with a small hole through which the cockroaches could come in and go out in a test container, and another new and vacant shelter was placed in the other, the movement frequency of male adults from one compartment to the other was much higher than that of female adults. The movement frequency of male adults increased with the increase of population density more sensitively than that of female adults. When female adults were released into a test container where only one shelter fully occupied by male adults had been placed, most of the male adults in the shelter were replaced by the female adults within 10 minutes. Female adults having fully occupied a shelter, however, were not replaced by introduced male adults. These results indicate that female adults prevail over male adults in their interaction for a suitable harbourage space, while male adults tend to seek new space more actively than female adults.
\end{abstract}

\section{INTRODUCTION}

We have found that the movement of adult German cockroaches, Blattella ger. manica (Linnaeus), from an old harbourage shelter to a new one is usually dependent on the increase of their population density. However, female adults sometimes did not move to the new shelter even under high density conditions, especially when there was a partition plate between the two shelters (Takahashi et al., 1996). The presence of food and water close to the old shelter tended to deter the cockroaches from moving to the new shel- ter (Takahashi et al., 1997).

In these experiments, however, the movement of individual cockroaches between the two shelter had not been examined. Therefore, experiments with marked individuals were conducted under the same conditions as used in the previous experiments using a partition plate with a small opening between two compartments in each of which was placed a harbourage shelter.

Other experiments were also carried out in order to evaluate the influence of some interaction between males and females on their harbouring behaviour, by giving only one shelter to them. Results of these 
experiments are reported here.

\section{Materials And Methods}

Exp. 1. Movement of marked cockroaches between two compartments. Adult German cockroaches, B. germanica (L.) (Watarida strain), were individually marked and numbered by adhibiting a very small piece of adhesive plaster sheet on the pronotum. Each of the shelters was a tier of two panels of $5 \times 5 \mathrm{~cm}$ size, a plywood floor panel and a plastic ceiling panel, with a $0.5 \mathrm{~cm}$ space between them. The plastic ceiling panel was transparent and orange-coloured, so that cockroaches did not avoid the shelter and could be easily observed. The shelter was essentially the same as that used in a previous experiment (Takahashi et al., 1996).

The test container was a plastic tray of $13 \mathrm{~cm} \times 22 \mathrm{~cm}$ and $6 \mathrm{~cm}$ height, which was divided into 2 compartments, $\mathrm{A}$ and $\mathrm{B}$, by a vinyl partition plate with a small central passage opening $(1 \times 0.5 \mathrm{~cm})$ at a height of $3 \mathrm{~cm}$ to allow cockroaches to move between the compartments. The top $4 \mathrm{~cm}$ inner surface of the tray and that of the partition plate were coated with paraffin oil to prevent cockroaches from escaping. Food and water were placed in both compartments.

First, a shelter was given to 16 or 32 cockroaches in a plastic cup ( $8 \mathrm{~cm}$ diameter, $4 \mathrm{~cm}$ depth). After 7 days, when all the cockroaches settled in the shelter, the shelter with the cockroaches was carefully taken out, transferred to the test container, and placed in the centre of one compartment (A) of the two. Then another (new and vacant) shelter was placed in the other compartment (B).

All the females are without egg case at the beginning of the experiment. However, about $2 / 3$ of the females surviving on the 12 th day had egg cases.

The experiments were carried out in $8 \mathrm{~h}$ dark and $16 \mathrm{~h}$ light at $25 \pm 1{ }^{\circ} \mathrm{C}$, under uncontrolled relative humidity ranging from 50 to $65 \%$. Two replicates were employed in each experiment.

Exp. 2. Interaction between males and females. The test container was a plastic tray of the same type as used in Exp. 1 (13 $\mathrm{cm} \times 22 \mathrm{~cm}$ and $6 \mathrm{~cm}$ height), but was not divided into two compartments. A shelter (also the same as that used in Exp. 1) occupied by 16 adults of one sex was placed in the centre, and then 16 adults of the other sex were introduced into the container.

Female adults used were taken from our stock culture at random, and about $2 / 3$ of them usually had their egg cases. They were provided with enough food and water during the experiment.

\section{RESULTS AND DISCUSSION}

1) Movement of individuals. Movement of individual males between $\mathrm{A}$ and $\mathrm{B}$ compartments in one of the replicates under the higher population density (32 per container) is shown in Fig. 1, and that of females in Fig. 2. In contrast with 16 among 30 females (Fig. 2), only 5 among 27 males (Fig. 1) were observed in A compartment every morning during the entire test period of 12 days. Similar results were obtained in another replicate.

Data for the lower population density (16 per container) were also determined in the same way as shown in Figs. 1 and 2, and movement frequency of the total number of cockroaches in the two replicates surviving at the 12 th day is shown in Fig. 3. The numbers of cockroaches surviving were $14+16=30$ males and 16 $+16=32$ females at the lower population density, and $27+17(7$ escaped $)=44$ males and $30+26=56$ females at the higher density.

Under the lower population density, $50 \%$ of males changed their harbourage compartment twice or more, whereas $28 \%$ of females did so. Under the higher density condition (32 per container), $69 \%$ of males changed the compartment twice or more, and so did about $36 \%$ of females.

Among the females, those with egg 
Time in days

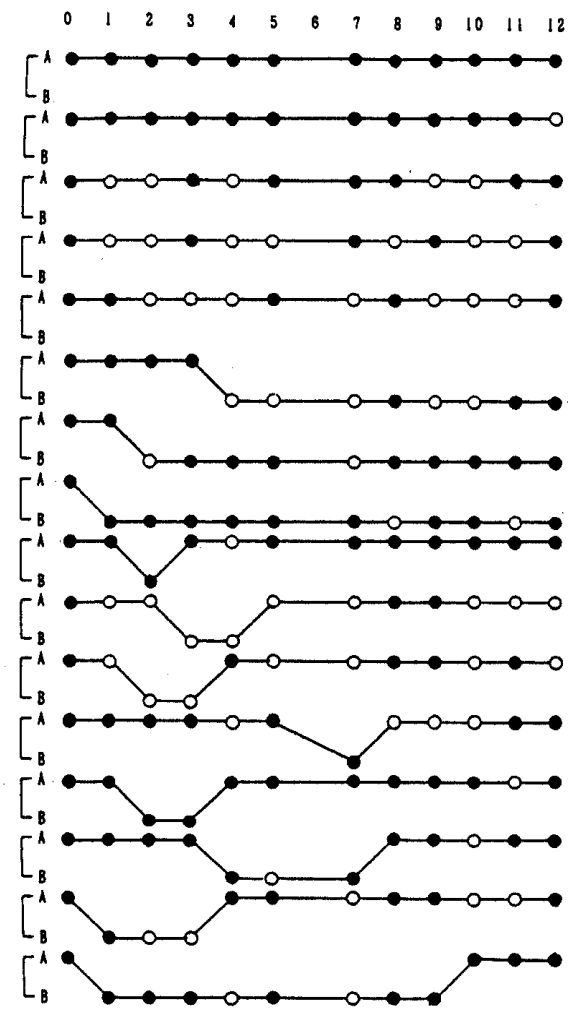

Time in days

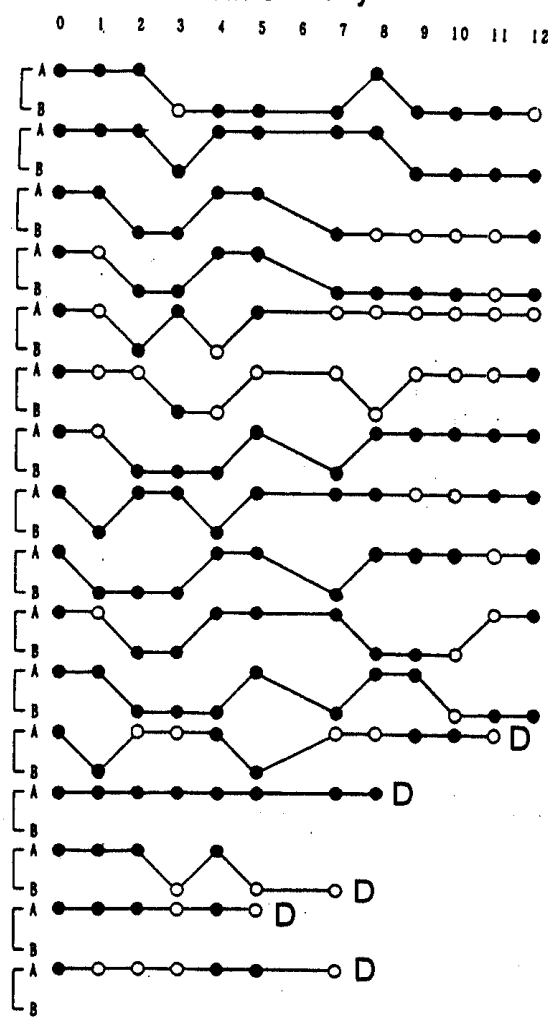

Fig. 1. Movement of 32 adult males between A and B compartments in a test container.

A, Compartment where an occupied harbourage shelter was placed; B, Compartment where a new shelter was placed; $O$, In the shelter; $O$, Outside the shelter; $D$, Death.

Time in days

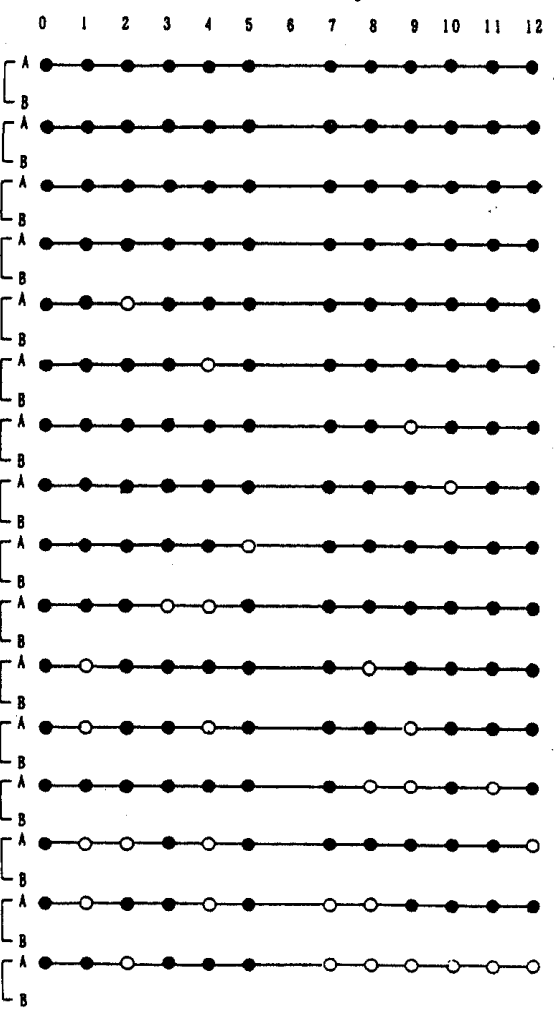

Time in days

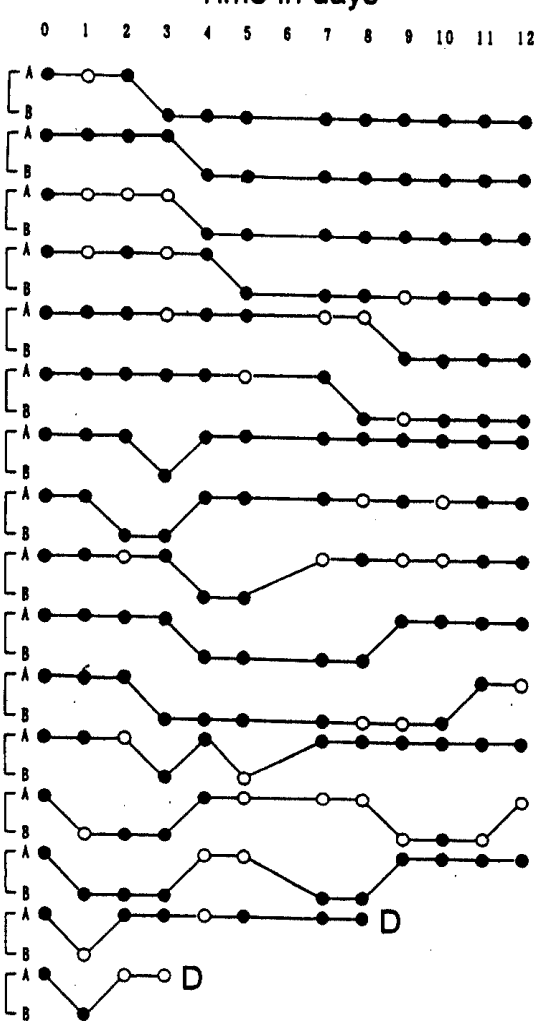

Fig. 2. Movement of 32 adult females between $A$ and $B$ compartments in a test container.

A, Compartment where an occupied harbourage shelter was placed; B, Compartment where a new shelter was placed; $O$, In the shelter; $\bigcirc$, Outside the shelter; D, Death. 

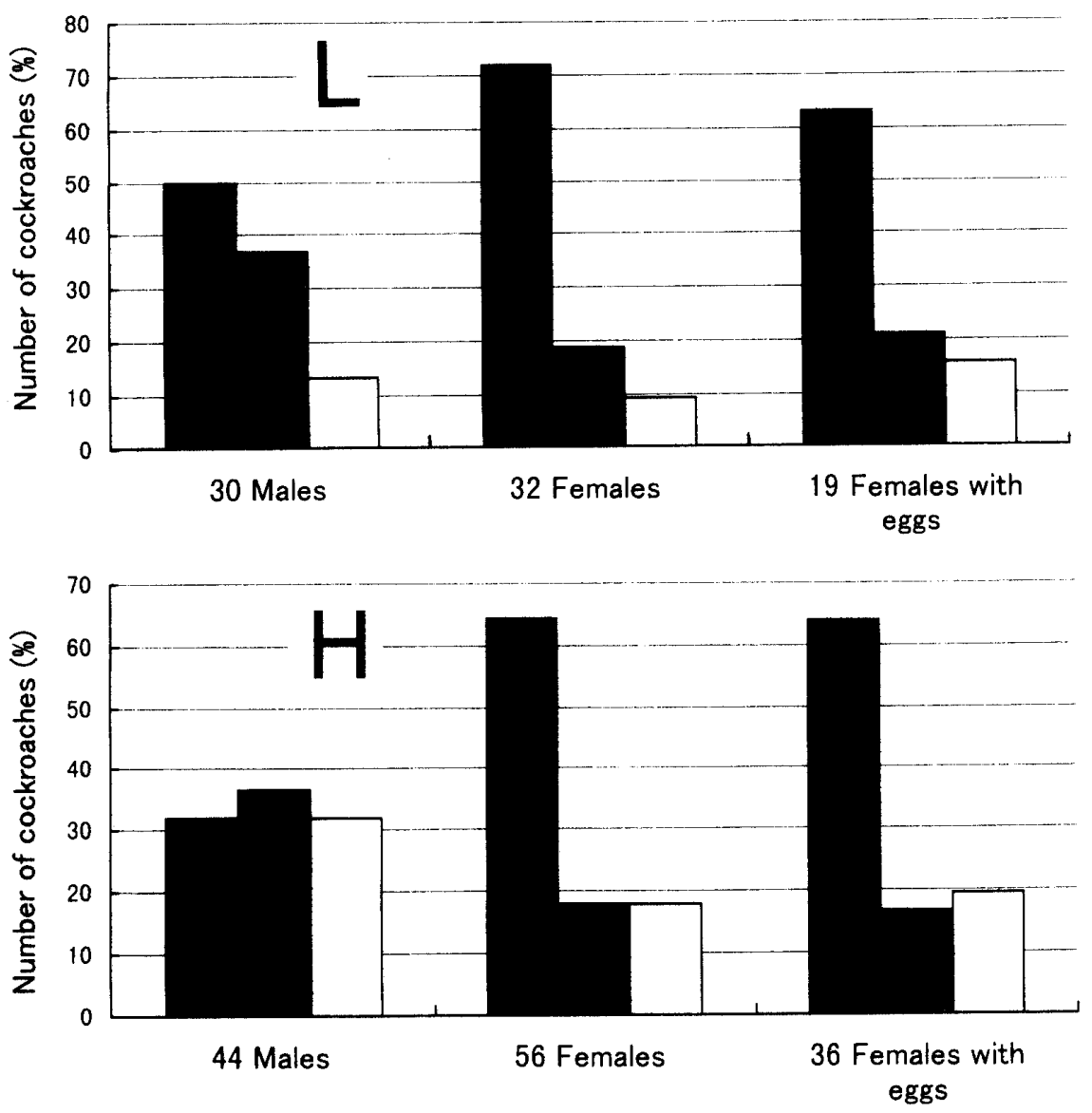

Fig. 3. Comparison of movement frequency of adult cockroaches between compartments during the test period (Total number of surviving cockroaches in two replicates).

Initial population density, L: $16, \mathrm{H}$ : 32 ; Movement frequency, $\square \leqq 1, \square=2, \square \geqq 3$.

cases were 19 and 36, at the low and high densities, respectively, on the 12 th day. The pattern of frequency composition for the females with egg cases was similar to that for the total females (Fig. 3).

Under the both population density conditions, 16, and 32 cockroaches per container, males were clearly more mobile than females between the two compartments, responding sensitively to the increase of population density (Fig. 3). The movement frequency of females did not increase so much as in males. The data suggest that female adults not only have less mobility (Kanayama et al., 1993), but also are not so sensitive as males to the increase of population density.

2) Interaction between males and females. When 16 females were released in a test container where 16 males had already occupied the shelter, the males tended to come out of the shelter, and most of the females entered the shelter within 60 minutes (Fig. 4A). After 60 minutes, the number of males remaining in the shelter was merely one-third of the initial number. Thereafter, the prevalence of the females in the shelter continued (Fig. 4B).

When males were released in a test container where females had already occupied the shelter, most of the males tried to enter the shelter within 10 minutes, but females did not come out of the shelter (Fig. 5A). Most of the males, however, could not stay longer in the shelter occupied by females (Fig. 5B). The results of a preliminary experiment carried out for 8 days were similar to those described here.

When females were released near to the shelter occupied by males (Fig. 4), many males quickly came out of the shelter and chased the females, taking a calling-pose. This indicates that most of the males spon- 

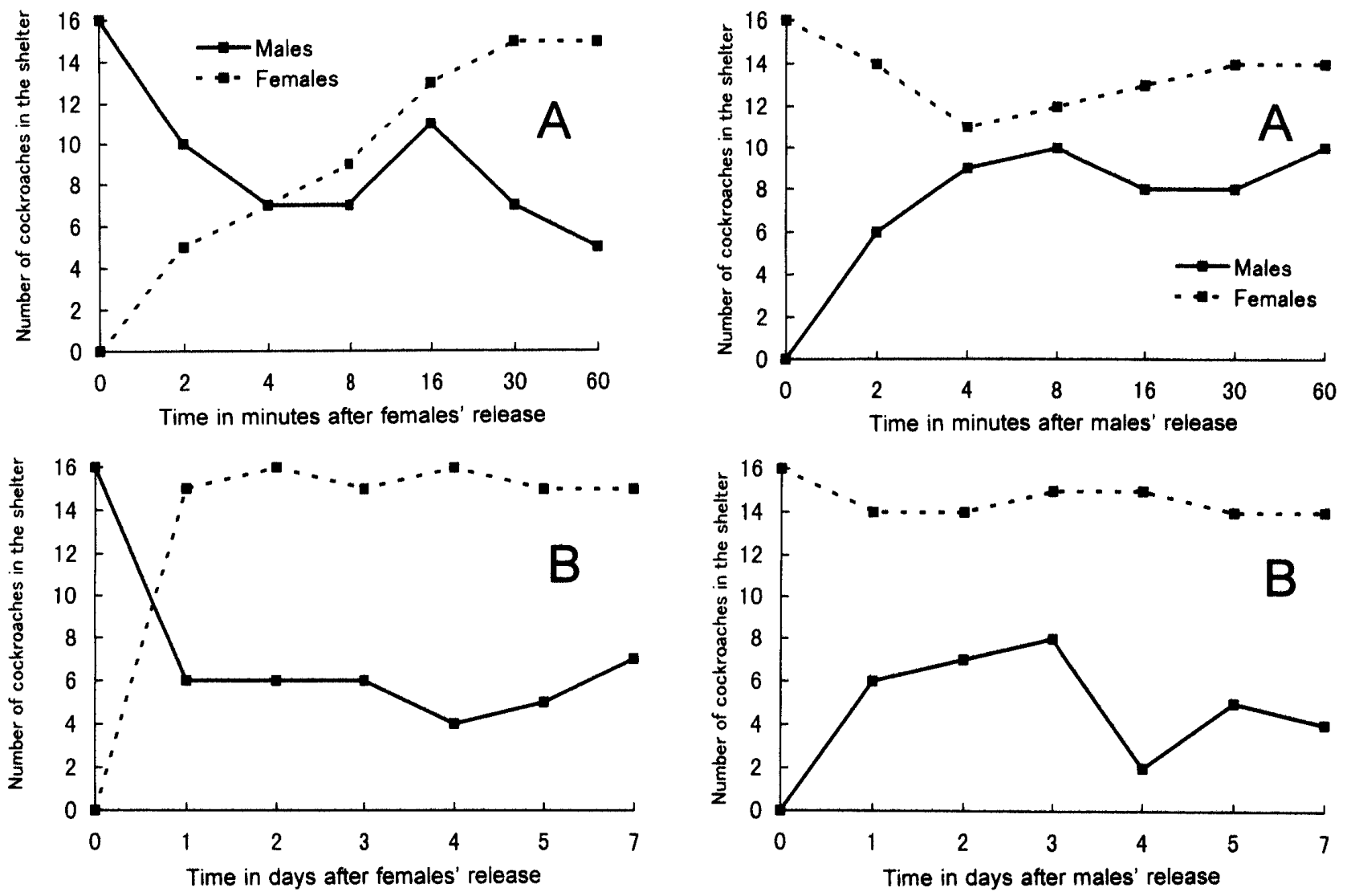

Fig. 4. Change in the number of cockroaches harbouring in the shelter.

Sixteen females were released in a test container where sixteen males had already occupied the shelter.

taneously left the shelter responding to the females to make copulation, while females entered the shelter pushing out males still remaining in the shelter, and prevailed over the males within $10 \mathrm{~min}$ utes. On the other hand, when females had already occupied the shelter, laterreleased males did not prevail over the females in the shelter (Fig. 5).

These results seem to show not only that females less frequently move about but that males and females have some interaction in the shelter and females can predominantly obtain the suitable harbourage space.

\section{REFERENCES}

Kanayama, A., K. Hirose and M. Toba (1993) Behavioural characteristics of the German cockroach, Blattella germanica (L.). Proceedings of the 1 st

Fig. 5. Change in the number of cockroaches harbouring in a shelter.

Sixteen males were released in a test container where sixteen females had already occupied the shelter.

International Conference on Insect Pest in the Urban Environment (ed., K. B. Wildey and W. H. Robinson), pp. 291-293, BPCC Wheatons Ltd., Exeter in England.

Takahashi, T., H. Tsuji, M. Ogiwara and M. Hatsukade (1996) Movement of adult German cockroaches, Blattella germanica (Linnaeus), from an occupied harbourage shelter to a vacant new shelter. 1. The influence of population density. Med. Entomol. Zool., 47: 363-369 (In Japanese with English abstract).

Takahashi, T., H. Tsuji, M. Ogiwara and M. Hatsukade (1997) Movement of adult German cockroaches, Blattella germanica (Linnaeus), from an occupied harbourage shelter to a vacant new shelter. 2. The influence of food and water location. Med. Entomol. Zool., 48: 33-37 (In Japanese with English abstract). 
摘要

チャバネゴキブリ成虫の新潜伏場所への移動

（第 3 報）雌雄間の相互干渉

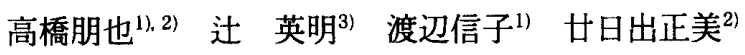

1) (株)フジ環境サービス

（テ421-0121 静岡市広野 5-5-7）

2) 静岡大学農学部応用昆虫学教室

（广422-8017 静岡市大谷 836）

3) 環境生物研究会

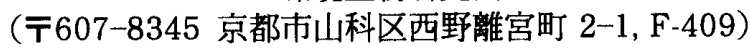

通行ロのあるバリヤーパネルで 2 分割した試験容器 の一方の区画内に，個体識別用にマーキングしたチャバ ネゴキブリ成虫が潜伏定着しているシェルターを置き,
他方の区画内に空の新しいシェルターを置くと, 通行口 を通る 2 区間の移動頻度は雄成虫が高く, 雌のそれは低 かった. また, 雄の移動頻度は個体群密度の増大に敏感 に反応して增大したが, 雌の移動頻度はあまり变わらな かった。

雄成虫が許容密度限度近く定着しているシェルターの 置かれた試験容器 (分割していない) 内に同数の雌成虫 を放すと, 10 分以内にシェルター内の大部分の雄が䊒 と入れ替わり，その後も倠が優勢に潜伏した，逆に，雌 成虫が定着しているシェルターの置かれた試験容器内に 雄成虫を放すと雌は優勢に潜伏したままで, 雄による置 き換わりは起こらなかった，以上のことは，雌成虫の移 動頻度が少ないことだけでなく, 雄成虫と雌成虫との間 に相互作用があり，雌成虫が優先的に潜伏することを示 している. 